\title{
A CALVINIST AND ANABAPTIST UNDERSTANDING OF THE BAN
}

\author{
MATTHEW SCOTT HARDING* \\ Southwestern Baptist Theological Seminary
}

\begin{abstract}
Amidst a growing renewal of interest in Calvinism and Calvin scholarship throughout the globe in the wake of John Calvin's 500th anniversary of his birth (1509-2009), this article focuses on John Calvin's early ecclesiological development. In contrast to advancing theories that Calvin developed his ecclesiological understanding of church discipline from earlier Anabaptist doctrines and leaders which he would have been exposed to intimately during his exile in Strasbourg (1538-1541), this article argues that Calvin had already determined and articulated a well-balanced and detailed understanding of the ban (church discipline) before his arrival in the protestant refuge city of Strasbourg. Further, this article argues that Calvin's sojourn and interaction with Anabaptists in Strasbourg cannot adequately explain Calvin's ecclesiological understanding or increasing practice of Church discipline in Strasbourg or Geneva, but rather displays a vivid disparity between Calvin and the Anabaptist position on the ban which Calvin denounces as false perfectionism.
\end{abstract}

KEY WORDS: John Calvin, Anabaptists, Church Discipline, the Ban, Perfectionism

Where John Calvin and the larger context of Anabaptists are concerned in the course of reformation history, one may concede the reality that there was truly "no love lost" between the two. As ardently as the predominant Anabaptist leaders directly attacked the magisterial reformed perspective of the Church, so John Calvin equally railed against the Anabaptists or "Catabaptists" as he called them, displaying great theological disparity between the two on no less than thirteen doctrinal issues. ${ }^{1}$

* Teacher and pastor, MATTHEW HARDING is pursuing his PhD in Historical Theology from Southwestern Baptist Theological Seminary, Ft. Worth TX and holds a D. Min. in Church Leadership.

1 Calvin used the term "Catabaptists" pejoratively on several occasions in reference to the Anabaptists in his writings Psychopannychia (1534) and The Institutes of the Christian Religion (1536). The term Catabaptistae translates as "down" or "against" baptism and 
Though there is a notable doctrinal divide between a large portion of reformed and Anabaptist ecclesiology, Calvin was able to edify the Anabaptists on their consistent use of the "ban", as a means of healthy church discipline. However, even on the matter of church discipline, Calvin strongly disagreed with the reason and theological presumptions Anabaptists embraced as they practiced church discipline within their communities. In essence, other than the doctrine of sola scriptura, there was little common ground between the Genevan magisterial reformer and the various groups of Anabaptists. Yet in spite of the historical evidence by Calvin's own hand, noted scholars such as Robert M. Kingdon and G.H. Williams have intimated that Calvin may have been directly or indirectly influenced in Strasbourg by Anabaptists and those close to them such as Martin Bucer in his ecclesiological development of church discipline. ${ }^{2}$

It is the purpose of this paper, however, to show that such an ecclesiological doctrinal development in Calvin-owing to an Anabaptist presence or practice of church discipline in Strasbourg, is unlikely. Thus, John Calvin's sojourn and interaction with Anabaptists in Strasbourg cannot adequately explain Calvin's ecclesiological understanding or increasing practice of Church discipline in Strasbourg or Geneva. Rather, this paper will demonstrate that prior to Calvin's temporary stay in Strasbourg (1538-1540) he had already developed and articulated a precise biblical position on the doctrine of church discipline and excommunication. Further, the author will argue that Calvin adamantly rejected the theological basis and spiritual presuppositions understood as "perfectionism" by which Anabaptists prac-

refers to Calvin's experience that the Anabaptists rejected infant baptism as a legitimate ordinance or proper practice of the biblical command of baptism. Willem Balke points out no less than thirteen areas in which Calvin was aware he differed with the Anabaptists including the nature of the church, the role of discipline, infant versus believer's baptism, the rightful place of the oath, civil authority, taxes, laws, the problem of pacifism, and opposition to tyranny. Willem Balke, Calvin and the Anabaptist Radicals (Grand Rapids: Eerdmans, 1981).

2 Kingdon states, "Between his stays in Geneva, Calvin spent a few years in Strasbourg as the pastor of a congregation of French refugees. This [time] was undoubtedly the period in which he became convinced of the need to introduce discipline into all Christian communities. One thing is sure: this idea played an essential part in the development of his thinking on his return to Geneva". Robert M. Kingdon, "Calvin and Ecclesiastical Discipline", ed. by David Hall, Tributes to John Calvin (Phillipsburg, NJ: P and R, 2010), 23. See also: G. H. Williams, The Radical Reformation (Kirksville, MO: Truman State Press, 2000), 898. Joyce C. Munro, ed., "The Anabaptists: Did You Know?" Christian History and Biography. Radical Reformation. The Anabaptists 5 (1985): 6. John Horsch, "Church Discipline", Mennonites in Europe (Halsey, OR: Rod and Staff, 1950), 348.

PERICHORESIS 10.2 (2012) 
ticed church discipline and therefore would not and did not emulate an "Anabaptist" practice, but employed a method and means of church discipline entirely unique to Calvin. ${ }^{3}$

\section{Church Discipline Defined}

The biblical concept of church discipline, also called the "ban" or excommunication, among Anabaptists leaders was so crucial to their understanding of the Church proper that they considered church discipline as a third mark of the church. ${ }^{4}$ Thus, in the majority of Anabaptist leaders and writers, one finds a superfluity of doctrinal descriptions of the necessity for and practice of the ban within the local church. Comparably, John Calvin also wrote at length concerning his foundational understanding of the doctrine of church discipline. Early in his pastoral and theological career in Basel, Geneva, and in Strasbourg, Calvin wrote a number of treatises, catechisms, ecclesiastical ordinances, letters, and his first edition of the Institutes (1536) in which he delineated the biblical mandate, reasoning, and practice of church discipline through excommunication.

\section{Anabaptist Understanding of the Ban}

Within the Anabaptist ranks throughout Europe, the ban or excommunication from the church was practiced through varying degrees of legalism to moderate chastisement, depending on the church leader. For example, Ulrich Stadler was known for his harsh interpretation of the ban, demanding an undefiled community, while Menno Simons pleaded for a sensible and spirit-led approach to church discipline, urging husbands and wives not to tians could attain perfection by no longer sinning in this life. It is to the evangelical Anabaptists which Calvin addresses this false presumption of perfectionism, and not toward the more radical rationalists or Libertines who at times were unfairly consolidated under the banner of "Anabaptism". K. H. Wyneken states that Calvin does not, however, "combine ideas from various theologies arbitrarily and facetiously. He knew how to distinguish between the perfectionism of the Libertines and of the Anabaptists, but he reduced them to a common denominator. Both believed that perfection is possible in this present life. The Anabaptist rigorists saw perfection as an obtainable goal; the Libertine perfectionists started with perfection as a bestowed reality for believers". K. H. Wyneken, "Calvin and Anabaptism", Concordia Theological Monthly 36 (1965): 24. For a variety of definitions of the Church which demonstrate that discipline acts as a third mark of the true church, see Walter Klassen, Anabaptism in Outline (Scottdale, PA: Herald, 1981), chapter 5 . 
be separated or others kicked out of homes. ${ }^{5}$ The ban, a practice of excluding a defiant parishioner from the faithful community of believers, is based on the scriptural command (Matthew 18:15-18), and included both the (1) "excommunication" from the church and her common table of the Lord's Supper (communion), and (2) "shunning", the total avoidance of said person in public (1 Corinthians 5:11). G. H. Williams states, "Baptism and the ban were the two keys controlling the entry to and the exit from the regenerate church of Anabaptism. By [re]baptism one entered the church. By the ban the wayward member was extruded. Only the pure could participate in the communion of the celestial flesh of Christ". ${ }^{6}$

Anabaptist leader, Menno Simons, articulated a strong doctrinal position on the ban. Simons states:

It is evident that a congregation or church cannot continue in the salutary doctrine and in a blameless and pious life without the proper use of discipline. Even as a city without a wall and gates, or a field without an enclosure or fence, or a house without walls and doors, so is also a church without the true apostolic exclusion. For it would be open to all deceiving spirits, all godless scorners and haughty despisers, all idolatrous and insolent transgressors, yes to all lewd debauchers and adulterers, as is the case with all the great sects of the world. In my opinion it is a vital characteristic, an honor and a means of prosperity for a true church to practice with Christian discretion the true apostolic exclusion and to observe it carefully with vigilant love according to the teaching of the holy divine Scriptures. $^{7}$

Therefore, Anabaptist Christians were taught to gather themselves into purified communities of true believers committed to the discipleship of Christ. Based on the preaching of God's Word as the sole source of authority, these Anabaptist communities were defined sacramentally through the baptism of holding that the exiled was not only banned but to be banished from the community entirely; to be expulsed inferred that the guilty would be cut off from all means of spiritual, social, and economic welfare. See Ulrich Stadler, Cherished Instructions on Sin, Excommunication, and Community of Goods, ed. by G. H. Williams, Library of Christian Classics, vol. 25 (Philadelphia: Westminster, 1958), 274-284, and Menno Simons, On the Ban. Questions and Answers, ed. by G. H. Williams, Library of Christian Classics, vol. 25 (Philadelphia: Westminster, 1958), 261-273.

6 G. H. Williams (ed.), Spiritual and Anabaptist Writers, Library of Christian Classics, vol. 25 (Philadelphia: Westminster, 1958), 261.

7 Menno Simmons. The Complete Works of Menno Simon (Elkhart, IN, 1871), 241.

PERICHORESIS 10.2 (2012) 
mature believers and the administration of the Lord's Supper. Thus, the "ban", a combination of community exile and excommunication from the presence and blessings of Christ, was used to punish backsliders.

Newly appointed Anabaptist leader, Michael Sattler scribed the Schleitheim Confession in 1527 only a few months before his arrest and murder. In the seven main articles describing the commitment to biblical Anabaptist principles, principles which were to be a rallying point for the many new converts to Anabaptism in Switzerland, Sattler pays special attention to defining the purpose and use of the ban. Sattler writes:

Article 2: The ban should be used against all who have given themselves to the Lord and agreed to follow his commandments, and who have been baptized into the one body of Christ, letting themselves be called brother or sister, and who nevertheless sometimes slip and fall into error and sin, and have been unknowingly overtaken. These people should be admonished twice privately and the third time should be punished or banned publicly, before the whole community, according to the command of Christ, [Matthew 18:1-18]. This banning should take place, according to the ordinance of the spirit [Matthew 5:23), before the breaking of bread, so that we are all of one mind, and in one love may break from one bread and eat and drink from one cup. ${ }^{8}$

Thus, for Sattler, the ban is weighed as a true punishment relating to the concept of separation and exile. Sattler further writes in the fourth article of the Schleitheim Confession, "we have agreed that a separation should take place from the evil which the devil has planted in the world. We simply will not have fellowship with evil people, nor associate with them, nor participate with them in their abominations". ${ }^{9}$

Further, another critical element which comprises the use of the ban is that it is carried out between two covenanted (baptized and confessed) members of the same local church. Thus, the authority to use the ban on another is rooted in the agreement accepted by every member of that local church to submit one's self under both the church's and pastor's spiritual authority. Balthasar Hubmaier states, "On what basis may a brother use this power over another? On the basis of the baptismal vow whereby man submits himself to the church with all its members. And what if the reproved sinner not amend? Then the church has the power and right to exclude

8 The Schleitheim articles (1527): As quoted in The Radical Reformation, ed. by Michael G. Baylor (Cambridge: Cambridge Press, 1991), 174. Ibid., 176. 
him as a perjurer and an oath-breaker and to put him under ban". ${ }^{10}$ Hubmaier continues:

The [ban] is an exclusion and separation of such a nature that from then on no Christian may have fellowship with such a man, not in words, meat or drink, in grinding or baking, or in any other way. He must consider him as a heathen and publican; that is an offensive, disorderly, and poisoned soul, who is bound and given over to the devil. One must avoid him and flee from him, lest by fellowship with him the whole church visible be evil spoken of, shamed, despised and deteriorated through his evil example. Rather a man is to be shocked through this punishmen 1 that he may examine himself, and die to his sins. For truly as God lives what the church binds or looses on earth is bound or loosed in heaven. ${ }^{11}$

Pilgram Marpeck, in his writings, also defines the ultimate purpose for the ban, underlying the unity and purity of the church. Marpeck states, "The other members of the body of Christ experience great pain and suffering, for at stake is a member of the body of Christ the Lord. They must lose a member in order that the other members, who are well are not hurt and the whole body destroyed". ${ }^{2}$ Continuing his reason, Marpeck resumes, "If, however, it allows the body no rest, nor improves by any medicine from the Lord Jesus Christ, through suffering and pain, it must be cut off in order that the other members of the body of Christ remain healthy in the fear and love of God and the neighbor, to whom alone the judgment to retain and to forgive sin has been committed". ${ }^{13}$ Menno Simons adds, "But those whom we cannot raise up and repentingly revive by admonition, tears, warning, rebuke, or by any other Christian services and godly means, these we should put forth from us, and not without great sadness and anguish of soul, sincerely lamenting the fall and condemnation of such a straying brother; in this way the ban is a great work of love". ${ }^{14}$

12 Pilgram Marpeck, “Judgment and Decision”, The Writings of Pilgram Marpeck (Scottdale, PA: Herald Press, 1978), 357.

Ibid., 357.

14 Menno Simons, "Admonition on Church Discipline", Complete Works on Menno Simons, ed. by J. C. Wenger (Scottdale, PA: Herald Press, 1956), 413. 


\section{Calvin's Understanding of the Ban}

As early as 1536, Calvin had articulated a well-developed doctrine on church discipline within his burgeoning ecclesiology. ${ }^{15}$ In Calvin's exegesis of the Apostles' Creed found in his first edition of the Institutes, he unpacks the need for and nature of proper church discipline in the form of excommunication. Calvin states:

For this use have excommunications been instituted, in order that those may be withdrawn and expelled from the gathering of the believers who, falsely pretending faith in Christ, by worthlessness of life and unbridled license of sinning, are nothing else than a scandal to the church, and therefore unworthy to boast in Christ's name (1 Corinthians 5:1-5; Matthew 18:15-19; 1 Timothy 1:20]. First: lest they be named among Christians with reproach to God, as if his holy church would be a conspiracy of evildoers and publicly wicked men; second, lest by frequent intercourse they corrupt others by the example of a perverse life; finally, that they may commence to repent, confounded by shame, and from that repentance they may at last learn to "wise up". ${ }^{16}$

Calvin also frequently noted the use and necessity of excommunication for maintaining a healthy church. In his answer and refutation of the Schleitheim Articles against the Anabaptist understanding of the ban, Calvin states, "We do not deny that the ban is a sound and holy order; not only useful but also necessary in the church... We constantly teach that the ban, which has been ordained by Jesus Christ, ought to be used; and we maintain that it is a ne-

In Calvin's Genevan Confession (1536), he states concerning excommunication: "Because there are always some who hold God and his Word in contempt, who take account of neither injunction, exhortation nor remonstrance, thus requiring greater chastisement, we hold the discipline of excommunication to be a thing holy and salutary among the faithful, since truly it was instituted by our Lord with good reason. This is in order that the wicked should not by their damnable conduct corrupt the good and dishonor our Lord, and that though proud they may turn to penitence. Therefore we believe that it is expedient according to the ordinance of God that all manifest idolaters, blasphemers, murderers, thieves, lewd persons, false witnesses, sedition mongers, quarrelers, those guilty of defamation or assault, drunkards, dissolute livers, when they have been duly admonished and if they do not make amendment, be separated from the communion of the faithful until their repentance is known". Jean Calvin, "The Confession of Faith” (1536), Calvin. Theological Treatises, ed. by J. K. S. Reid, Library of Christian Classics, vol. 22 (Philadelphia: Westminster, 1954), 31.

16 John Calvin, Institutes of the Christian Religion (1536), Ford Lewis Battles, trans. (Grand Rapids: Eerdmans, 1975), II.26. 
cessary means for preserving the church". ${ }^{17}$ Calvin continues, "We confess that it is certainly an imperfection and an unfortunate stain in a church where this order [excommunication] is absent... And when the ban is not practiced at all, then the true form of the church is to that extant disfigured". ${ }^{18}$

Further, in Calvin's Instruction in Faith (1537), his first Genevan Catechism which contained a cursory summary of his Institutes and acted as a primer on the necessities of Christian faith, he outlines the bitter necessity and spiritual reality of excommunication in the local church. Calvin writes:

Excommunication is the act whereby those who are manifestly fornicators, adulterers, thieves, homicides, misers, robbers, iniquitous, pernicious, voracious, drunkards, seditious, and prodigal (if they do not amend themselves after having been admonished) are, according to God's commandment, rejected from the company of believers. The Church does not thereby cast them into perpetual ruin and despair. She simply condemns their ways of life and their manners, and, if they do not correct themselves, she makes them already certain of their condemnation. Now this discipline is necessary among believers because, as the Church is the body of Christ, she must not be polluted and contaminated by such stinking and rotten members. This discipline is profitable also to the latter themselves that their malice be thereby thus chastised; this disciplinary provision confuses them with shame and teaches them to amend themselves. When this result is obtained, the Church with kindliness will receive them again in her communion and in the participation of that union from which they had been excluded..$^{19}$

Akin to the Anabaptist understanding of the foundational ecclesiological nature of the ban, Calvin also held that the mark of church discipline was vital to a proper conception of the true Church. As newly appointed pastor in Geneva in 1537, Calvin preceded to re-organize the church and city in Geneva toward a biblical practice of church discipline. Describing the foundational role discipline assumes for the very existence of Christ's Church on the earth, Calvin states: 
Having then considered that a Church cannot retain its true condition without observing this ordinance [excommunication], and that it is greatly to be feared that contempt of it may be punished by the mighty vengeance of God, the expedient thing seemed to us to be what was committed to the Church and exercised according to the rule which we have in Scripture. ${ }^{20}$

Unfortunately for Calvin and William Farel, it was this strong conception for the necessity of enforceable church discipline to bring order to the city and Geneva's churches which set the stage for their subsequent political demise and eventual expulsion from Geneva. ${ }^{21}$

However strong a tone Calvin takes in the enforcement of the church ban, he also shows his pastoral heart and the caution by which one should proceed enacting the ban. For Calvin, the base motivation for the temporary ban was biblical restoration. Accordingly, Richard De Ridder holds that "Calvin nowhere compromises the duty of fellow believers to accept and practice the responsibility they have to one another when a member falls into sin. Indeed, he remains firm in the conviction that the major goal of discipline is the salvation of sinners, through whose recovery God receives vin. Theological Treatises, Library of Christian Classics, vol. 22 (Philadelphia: Westminster, 1954), 52. Calvin continues: If it be found that such remonstrances have no result, he must be advised that his obstinacy will be reported to the Church. And then if he recognizes his error, how great is the profit of this discipline! If he does not attend to it, the time has come when the minister appointed by those who are in charge of the case should announce publicly in the assembly what has been done to bring him to amendment and all without result. By then it will be realized whether he will persevere in hardness of heart, and this is the time for excommunication. That is to say, he is to be held as expelled from the company of Christians and left in the power of the devil for his temporal confusion, until he give good evidence of his penitence and amendment; and as sign of this he is to be barred from the communion of the Supper, and denounced to other believers that they have no intimate dealings with him. But he is never to omit coming to sermon to receive teaching, in order to prove whether it will please the Savior to touch his heart and turn him into the right path (Italics added for Emphasis), 52.

21 For a detailed account of the proceedings immediately before Calvin and Farel are dismissed from Geneva in 1538, see William J. Bouwsma, John Calvin. A 16th Century Portrait (Oxford: Oxford University Press, 1988), 191ff. Bernard Cottret, Calvin. A Biography (Edinburgh: T\&T Clark, 1995); Bruce Gordon, Calvin (New Haven: Yale, 2009); and a detailed bibliography for this event is found in Herman J. Selderhuis, The Calvin Handbook (Grand Rapids: Eerdmans, 2009) among others.

PERICHORESIS 10.2 (2012) 
his glory and the church is freed of offenses". ${ }^{22}$ Exercising caution toward the ban, Calvin likewise declares:

Let us not claim for ourselves more license in judgment, unless we wish to limit God's power and confine his mercy by law. For God, whenever it pleases him, changes the worst men into the best, engrafts the alien, and adopts the stranger into the church. And He does this to frustrate men's opinion and restrain their rashness-which venture to assume for themselves a greater right of judgment than is fitting... Consequently, though ecclesiastical discipline does not permit us to live familiarly or have intimate contact with excommunicated persons, we ought nevertheless to strive by whatever means we can, whether by exhortation and teaching or by mercy and gentleness, or by our own prayers to God, that they may turn to a more virtuous life and may return to the society and unity of the church. ${ }^{23}$

In his lengthy discussions toward the right perception of the nature of the true church, Calvin as a young pastor and theologian articulates a precise and developed understanding of church discipline. Well before his threeyear sojourn in Strasbourg (1538-1541), where he would have intimate contact with Anabaptist leaders and churches, Calvin delineated a highly evolved and comprehensive biblical doctrine of church discipline. Being not only a theologian but also pastor, Calvin demonstrated his compassion and ultimate desire to see the spiritually wayward fully restored to the Church through means of the temporary ban.

Calvin attacks the Anabaptist use of the ban, seeing it as a form of punishment rather than a gracious tool of correction toward the restoration of the soul. Echoing Calvin's sentiments, Benjamin Farley notes, "To use the ban as the Anabaptists wish is to turn it into a form of punishment rather than a means of grace. Christ came to forgive sin. The state exists to punish sin. But the Anabaptist use of the ban makes Christ the punisher". ${ }^{24}$ Thus, an initial observation into the differences between how the Anabaptists understood and practiced the ban in contrast with Calvin reveals a fundamental difference in both motivation and biblical presupposition.

24 Farley, Treatises, 30.

PERICHORESIS 10.2 (2012) 


\section{Calvin's Problem with Anabaptist Understanding of the Ban}

As Calvin reflected upon the sectarian Anabaptists of his day, he understood that they based their ecclesiology both in theory and in practice on a faulty biblical assumption of perfectionism. ${ }^{25}$ For Calvin, the erroneous conception of spiritual perfectionism as a foundational element to Anabaptist ecclesiology unfortunately led them to separate from the true mother Church and in turn, practice harmful, punitive, and non-restorative church discipline. ${ }^{26}$ Calvin scholar K. H. Wyneken states:

[For Calvin] the error at the bottom of their sectarianism and puritanism was a misguided perfectionism, the claim that believers no longer sin. If anyone feature of Calvin's views [toward Anabaptists] stands out, it might be his belief that the faulty perfectionism of most of the sectarians cast its shadow over their theology. It affected both their attitude toward civil authority and their ecclesiology, not to mention whatever adverse affect it may have had on their personal beliefs and piety. This is perhaps the outstanding insight developed with consistency in the anti radical polemics of the Institutes. ${ }^{27}$

\section{Anabaptists as Separatists}

Calvin began his polemical treatises against the evangelical Anabaptists highlighting their conception of the church as the pure, perfected community of saints. Since the Anabaptists believed that a third mark of the true Church was the ban, anywhere they did not see it practiced among churches they immediately rejected those churches (and leaders within them); ${ }^{28}$

25 See footnote 4. The author realizes that Calvin's perception of Anabaptist practice of the ban may not have been intrinsically linked to all evangelical Anabaptists' understanding of perfectionism; rather, the author is attempting to demonstrate that Calvin was convinced through his personal contacts with Anabaptist leaders and churches, letters, and mutual friends that the majority of Anabaptists held to a false biblical concepttion of perfectionism which erroneously led them to separate from the Church and practice the ban as punishment to the ultimate spiritual harm of the guilty. Hence, Calvin would never have considered himself linked with or influenced by Anabaptist ecclesiology.

26 Calvin's focal problem with Anabaptists is based on the reality that they have separated from the true church, causing disunity and confusion among evangelical believers and allowing for more generalized attack from the papists. Calvin believes that the main reason for this bold separation of the Anabaptists from the true Church lies in the mistaken ideal that Christians are to be perfect in all aspects in this life, being summarily excommunicated from the church if they fail in the least to uphold a life of perfection. Wyneken, "Calvin and Anabaptism", 12.

28 Twentieth century scholars Richard Stauffer, Willem Balke, and Benjamin Farley, each held that Calvin so disliked the biblical characterization of perfectionism as it causally 
Calvin remarked that the Anabaptists even associated the reformed church with the Antichrist because church discipline was not regularly enforced throughout. ${ }^{29}$ Subsequently, Calvin chastises the Anabaptists for separating from the Reformed Church to form their own pure and local expressions of the community church based on their "faulty" biblical presumptions. ${ }^{30}$

In the first edition of the Institutes (1536), Calvin's initial conception of the Church centered on the idea that the Church of Christ consists of a unified and catholic society because "there could not be two or three churches... They are dependent on one Head and they also grow together into one body, being joined and knit together". "Calvin refers to the Church as the "mother of believers" and "the mother of us all;" ${ }^{22}$ Calvin utilizes this spiritual analogy to indicate the utter faithlessness of those who

related to Anabaptist church discipline that he refused to raise church discipline to the rank of a third true mark of the church, following the Word rightly preached and the Ordinances rightly administered. Farley relates that Stauffer credits Calvin with the realization that "the Anabaptists had made the ban a defining characteristic of the church. This introduced a form of perfectionism that Calvin inveighed against; hence he avoided the snare of making discipline a 'third mark' of the church". John Calvin, Treatise against the Anabaptists and Libertines, ed. and trans. by Benjamin W. Farley (Grand Rapids: Baker, 1982), 28. See Richard Stauffer, "Zwingli et Calvin: Critiques de la Confession de Schleitheim", ed. by Marc Lienhard, The Origins and Characteristics of Anabaptism (The Hague: Martinus Nijhoff. 1977), 134.

29 Willem Balke, Calvin and the Anabaptist Radicals (Grand Rapids: Eerdmans, 1981), 114. Calvin understands first-hand that the Anabaptists have withdrawn from the churches in Geneva and Strasbourg, noting their disgust at the tolerance of "unfit" or known sinners being allowed participation in communion. Calvin states, "They separate themselves from the churches in which the doctrine of God is purely preached, taking this pretext: that they do not care to participate in the pollution committed therein, because those who ought to be excommunicated have not been banished. Calvin, Treatises, 57.

30 Calvin expends enormous energy in polemicizing the Anabaptists through a massive restructuring of his second edition of the Institutes (1539) [Balke surmises that the entire first section of book four of the Institutes is "directed specifically against the Anabaptist denial that a church exists when it is not completely pure. It also offers a serious rebuke to the sectarian claims of superiority" (Balke, 117)], his initial publishing of Psychopannychia (1534) published in 1542, and through his Brief Instruction (1544) in the Treatises Against the Anabaptists. The point being that Calvin saw immense danger in the form of sectarianism based on poor theology which the Anabaptists believed and practiced and he felt spiritually obligated to castigate theologically the radicals, while attempting vigorously to bring them back into the established "Mother" Church.

31 Calvin, Institutes (1536), 4.1.

32 John Calvin, Commentaries on the Epistles of Paul to the Galatians (Grand Rapids: Baker, 2009), 141.

PERICHORESIS 10.2 (2012) 
would separate and reject the established and unified Church, especially since "while we remain within the bosom of the church, the truth will always abide with us". ${ }^{33}$ In the Institutes, Calvin then distinguishes between departures in doctrine and in life; concurrently Calvin held that separation was permissible only when the main points of doctrine are at issue, such as he and the other magisterial reformers exemplified in leaving the Roman Catholic Church. For Calvin, the Anabaptists had no true doctrinal foundation for separation. ${ }^{34}$

It is in the context of the argument concerning the unity of the church and the necessity to remain true to its divine form that Calvin first mentions the dual image of the invisible and visible church (ecclesia visbilis). Calvin states, "How we are to judge the church visible, which falls within our knowledge, is, I believe, already evident from the Scripture" ${ }^{35}$ Calvin holds that the invisible Church is the Church as it really is before God, the True and Righteous Judge who sees and judges perfectly the lives of men; the visible church, then, is the church as it appears to man. Calvin elaborates:

In this Church there is a very large mixture of hypocrites, who have nothing of Christ but the name and outward appearance: of ambitious, avaricious, envious, evil-speaking men, some also of impure lives, who are tolerated for a time, either because their guilt cannot be legally established, or because due strictness of discipline is not always observed. Hence, as it is necessary to believe the invisible Church, which is manifest to the eye of God only, so we are also enjoined to regard this [visible] Church which is so called with reference to man, and to cultivate its communion. ${ }^{36}$

Thus, as the foundational concept of his vision for the visible Church-expressed through local churches around the world-Calvin accepts the reali-

Ibid., 141.

The official ministry of the Word and the sacraments, according to Calvin, must be emphasized more strongly: "In this way we preserve for the universal church its unity, which devilish spirits have always tried to sunder" (4.1.9). Calvin condemns every tendency toward separation, believing that Separation is the work of the devil: "For there is nothing that Satan plots more than to... drag us away from the church" (4.1.11). "For the Lord esteems the communion of his church so highly that he counts as a traitor and apostate from Christianity anyone who arrogantly leaves any Christian society, provided it cherishes the true ministry of Word and sacraments" (4.1.10).

All subsequent references to Calvin's Institutes, editions 1539 and later will be cited simply as: Institutes, 4.11.1.

Institutes, 4.1.7. 
ty that the church discernible will always be comprised of the lost, the saved (elect), and those believers who struggle to maintain a life of purity needing the church's help. Since these visible churches each preach the Word and rightly administer the sacraments, they belong to the one true invisible and "mother" Church, who is called the bride of Christ (Revelations 19:7). Calvin attacks the Anabaptists for propagating that any church which does not practice church discipline can be considered pure or part of the true church. Calvin states, "If the ban is not practiced at all, then the true form of the church is to that extant disfigured. But this is not to say that the church is wholly destroyed and the edifice no longer stands, for it retains the teaching on which the church must be founded". ${ }^{37}$

In all of Calvin's writings toward biblical excommunication, he advances that greater improvement must be made toward reconciling local churches to the biblical mandate of faithful church discipline; yet, he holds the Anabaptists guilty of dissention and needless separation based on false perceptions that the true church is comprised of and must remain pure with perfect saints. Calvin adamantly concludes his thought on the form of the true church as it relates to unity and perseverance stating, "the pure ministry of the Word and pure mode of celebrating the sacraments are... sufficient pledge and guarantee that we may safely embrace as church any society in which both these marks exist... We must not reject it so long as it retains them, even if it otherwise swarms with many faults" 38 Calvin later posits, "Until the Day of Judgment, they are vainly seeking a church besmirched with no blemish... Rather, how much more important both the ministry of the Word and participation in the sacred mysteries are for the gathering of the church than the possibility that this whole power may be dissipated through the guilt of certain ungodly men". ${ }^{39}$ Balke concludes, "In this way Calvin takes his stand in opposition to the separatism of the Anabaptists, who wanted to strive for a church made up only of perfecti, or an ecclesia perfecta". ${ }^{40}$

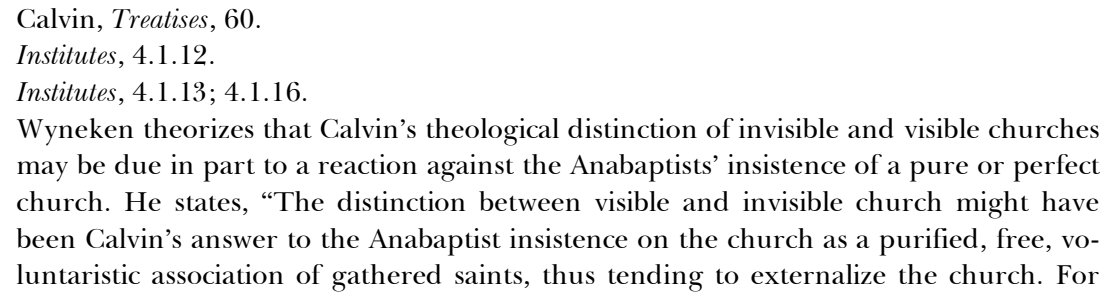
may be due in part to a reaction against the Anabaptists' insistence of a pure or perfect church. He states, "The distinction between visible and invisible church might have been Calvin's answer to the Anabaptist insistence on the church as a purified, free, voluntaristic association of gathered saints, thus tending to externalize the church. For 


\section{Perfectionism and the Ban}

Rivaled with Calvin's disenchantment toward Anabaptist separatist tendencies was his distaste for the legalistic rigor placed upon Christians within Anabaptist communities. More than simple piety or striving toward godliness, Calvin felt the idea of spiritual perfectionism was a gross misperception of the Bible's teachings and was the fruit of faulty presuppositions on behalf of both evangelical and Libertine Anabaptist leaders. At stake for Calvin was the real opportunity for full restoration or initial salvation in the lives of those who had been banned from Anabaptist communities.

Comparing the Anabaptists of his day to the Cathari, Novatianists, and Donatists of old, Calvin equates these groups' false notion of "perfect" spiritual attainment on the earth with the damaging and impractical optimism found in faulty perfectionism, which he adduced to the Anabaptist practice of the ban. Calvin states:

The Novatians, in ancient times, agitated the Churches with this dogma, but in our day, not unlike the Novatians are some of the Anabaptists, who have fallen into the same delirious dreams. For they pretend that in baptism, the people of God are regenerated to a pure and angelical life, which is not polluted by any carnal defilements. But if a man sin after baptism, they leave him nothing except the inexorable judgment of God. In short, to the sinner who has lapsed after receiving grace they give no hope of pardon, because they admit no other forgiveness of sins save that by which we are first regenerated. ${ }^{41}$

Calvin the church consisted, it is true, of saints but with sinners and hypocrites still hidden amidst the saints". Wyneken, "Calvin and Anabaptism", 10.

41 Institutes, 4.1.23. Calvin Continues: Our indulgence ought to extend much farther in tolerating imperfection of conduct. Here there is great danger of falling, and Satan employs all his machinations to ensnare us. For there always have been persons who, imbued with a false persuasion of absolute holiness, as if they had already become a kind of aërial spirits, spurn the society of all in whom they see that something human still remains. Such of old were the Cathari and the Donatists, who were similarly infatuated. Such in the present day are some of the Anabaptists, who would be thought to have made superior progress ... For where the Lord requires mercy they omit it, and give themselves up to immoderate severity. Thinking there is no church where there is not complete purity and integrity of conduct, they, through hatred of wickedness, withdraw from a genuine church, while they think they are shunning the company of the ungodly. They allege that the Church of God is holy. But that they may at the same time understand that it contains a mixture of good and bad, let them hear from the lips of our Savior that parable in which he compares the Church to a net in which all kinds of fishes are taken, but not separated until they are brought ashore. Calvin, Institutes, 4.1.13 (Italics added for emphasis). 
Contrastingly, Calvin notes, "In bearing with imperfections of life we ought to be far more considerate". ${ }^{42}$ Calvin advances the spiritual reality that the church has always contained those hidden deceivers and liars, yet that it was up to God's perfect scrutiny and impeccable judgment to discern between the wheat and tares (Matthew 13). Calvin notes that the Corinthian church was full of those erring believers, yet Paul still held the Corinthian society of believers as a true church.

Calvin's love for the holiness of the church was always limited by his rejection of rigorism, the exacting of punishment for those failing to maintain perfection in life.

However good, beneficial and salutary the Church may be, Calvin hesitated to overstate the necessity of the individual's personal holiness as a direct correlation to the church's purity and perfection. Since Calvin held that the church's holiness and purity are derived directly from Christ, he understood that individual Christians are constantly on the journey toward greater holiness as they appropriate Christ's grace and spiritual power. For Calvin, the true Church, the visible Church, consisted of those who had been saved and yet not glorified. Calvin did not demand perfection of the believer as a prerequisite for communion, nor condition to remain within fellowship of the church. Reflecting on the holiness of the church, Calvin observes, "If we are not willing to admit a church unless it be perfect in every respect, we leave no church at all". ${ }^{43}$

Balke comments, "No matter how much Calvin may be considered the theologian of sanctification, he hesitates to set up a criterion of holiness for the church". ${ }^{44}$ Calvin concludes, "Therefore let that serve us as a warning that whenever, under the pretext of a zeal for perfection, we cannot tolerate any imperfection, either in the body or the members of the church, then the devil inflames us with pride and seduces us through hypocrisy to leave

42 Institutes, 4.1.13.

43 Calvin, Institutes, 4.1.17. It is true, indeed, as Paul says, that Christ "loved the church, and gave himself for it, that he might sanctify and cleanse it with the washing of water by the word, that he might present it to himself a glorious church, not having spot, or wrinkle, or any such thing; but that it should be holy and without blemish" (Ephesians 5:25-27). Nevertheless, it is true, that the Lord is daily smoothing its wrinkles, and wiping away its spots. Hence it follows, that its holiness is not yet perfect. Such, then, is the holiness of the Church: it makes daily progress, but is not yet perfect; it daily advances, but as yet has not reached the goal. 
the flock of Jesus Christ, knowing that he has won everything when he has withdrawn us from the church. ${ }^{45}$

\section{Conclusion}

From the very beginning of Calvin's ecclesiological understanding of the ban, he felt that the reformed church should take a firm stand and re-initiate excommunication in every local body, where the church-not the state-handled all biblical and sinful issues unrelated to civil crime. Unique to Calvin, however, was the concept of the consistory, a separate spiritual body of elected men and pastors to oversee the ban within a city or church parish. Perhaps more than any other magisterial reformer, Calvin understood, articulated, and enforced church discipline in the areas of his influence.

However, even though the Anabaptists leaders lived and wrote about the ban a generation before Calvin, and in spite of Calvin's intimate knowledge and dealings with Anabaptists in Geneva and Strasbourg, no intrinsic evidence suggests that the Anabaptists influenced (directly or indirectly) Calvin's ecclesiological development of church discipline. Conversely, noted scholars are intrigued about the possible influences on Calvin's ecclesiology in terms of church discipline from men such as Oecolampadius, Farel, and Lambert of Avignon. ${ }^{46}$

In this paper, the author has attempted to demonstrate that prior to Calvin's temporary stay in Strasbourg (1538); he had already clearly articulated a comprehensive biblical conception of appropriate and effective church discipline. In his Institutes, Ordinances, Articles of Organization, and Confession of Faith (all written prior to 1538), Calvin demonstrates a focused mastery of the biblical mandate toward excommunication. Further, in his writings, Calvin vehemently protests the motivation and misguided presuppositions of perfectionism which he felt Anabaptists employed as their basis for communal separation and practice of the ban. Calvin pleaded with Anabaptists to return to the mother church, to be restored themselves, and then to embrace a biblical understanding of the ban as means of spiritual restoration (and not punishment). In light of the historical evidence from Calvin's own

$45 \quad$ Calvin, Treatises, 71.

46 See J. Wayne Baker, "Christian Discipline and the Early Reformed Tradition: Bullinger and Calvin" and A. Demura, "Calvin's and Oecolampadius' Concept of Church Discipline", Articles on Calvin and Calvinism, ed. by Richard Gamble (New York: Garland, 1992), 279-303; and Fuhrman, 78. 
life, theology, and ecclesiological practices, it would be an improbable conclusion to believe that Anabaptists had any significant affect on Calvin's ecclesiological developmental of church discipline.

\section{Bibliography}

Primary Sources

Barth, Peter and Wilhelm Niesel, eds. Ioannis Calvini opera selecta. Cinque Tomes. München: Chr. Kaiser, 1926-62.

Bonnet, Jules, ed. Lettres de Jean Calvin, Lettres Françaises. Two volumes. Paris: Meyrueis, 1854.

Calvin, John. Selected Works of John Calvin. Tracts and Letters. Edited by Henry Beveridge and Jules Bonnet. Grand Rapids, MI: Baker Book House, 1983.

Calvin, John and Sadoleto, Jacopo. A Reformation Debate. Edited by John C. Olin. Grand Rapids, MI: Baker Book House, 1976.

. The Instruction in Faith (1537). Edited and translated by P. T. Fuhrman. Philadelphia, PA: Westminster Press, 1949.

. Commentaries on the Epistles of Paul. Grand Rapids, MI: Baker, 2009

. Institutio christianae religionis [1559). Volumes 3-5 of Iohannis Calvini opera selecta. Edited by P. Barth and W. Niesel. München: Chr. Kaiser, 1957-62.

. Institutes of the Christian Religion (1536). Translated by Ford Lewis Battles. Grand Rapids, MI: Eerdmans, 1975.

. "Institutes of the Christian Religion". Library of Christian Classics, 2 volumes. Edited by John T. McNeill, volume 20. Philadelphia, PA: Westminster, 1954.

. Opera Quae Supersunt Omnia. 59 Tomes. Volumes. 5-10. Braunschweig, 1863-1900.

. Opera omnia, series VI, Epistolae. Geneva: Droz, 2005.

. Corpus reformatum. Ioannis Calvini opera quae supersunt omnia. Edited by Baum, Cunitz, and Reuss. Berlin-Brunswick, 1859-1900.

. "Theological Treatises". Library of Christian Classics. Volumes 22. Philadelphia, PA: Westminster, 1954.

. Treatises against the Anabaptist and Against the Libertines. Edited by Benjamin W. Farley. Grand Rapids, MI: Baker, 1982.

Herminjard, Aimé Louis, 1817-1900. Correspondance des réformateurs dans les pays de langue française, recueillie et publiée avec d'autres lettres relatives à la 
réforme et des notes historiques et bibliographiques. Geneve: R. Georg, 1868. Letters of John Calvin. Edinburgh: Banner of Truth Trust, 1980.

Les Lettres A Jean Calvin. De La Collection Sarrau. Paris: Presse Universitaires, 1972.

Luther, Martin. "The Small Catechism and the Large Catechism". Book of Concord. Second edition. Saint Louis, MO: Concordia, 2006.

Secondary Sources

Achtemeier, Mark P. Reflections on Calvin's Catechetics in Calvin Studies VI. Davidson, NC: Davidson College, 1992.

Ainslie, James, L. The Doctrine of Ministerial Order in the Reformed Churches of the 16th and 17th Centuries. Edinburgh: T\&T Clark, 1940.

Anrich, G. Strassburg und die Calvinische Kirchenverfassung. Tübingen, 1928.

Arnold, Matthieu. Jean Calvin. Les annees strasbourgeoises (1538-1541). Strasbourg: Presses Universitaires De Strasbourg, 2010.

Avis, Paul. Church and Theology of the Reformers. London: Marshall, Morgan, and Scott, 1981.

Balke, Willem. Calvin and the Anabaptist Radicals. Translated by William Heynen. Grand Rapids, MI: Eerdmans, 1981.

Beeke, Joel, R. Calvin for Today. Grand Rapids: Reformation Heritage, 2009. . Living for God's Glory. Grand Rapids, MI: Reformation Heritage, 2008.

The Quest for Full Assurance. The Legacy of Calvin and His Successors. Carlisle, PA: Banner of Truth. 2000.

Benedict, Philip. Christ's Churches Purely Reformed. A Social History of Calvinism. New Haven, CT: Yale, 2002.

Benoît, J. D. Calvin à Strasbourg, Strasbourg, 1938. . Calvin, Directeur D'ames. Strasbourg: Oberlin, 1947.

Berthoud, Jean-Marc "John Calvin and the Spread of the Gospel in France". Fulfilling the Great Commission. Westminster Conference Papers, London: Westminster Conference, 1992.

Bornert, Rene. La Reforme Protestante du culte a Strasbourg au XVI siecle (15231598). Approache sociologique et interpretation theologique. Leiden: Brill, 1981.

Bouwsma, William. John Calvin. A Sixteenth Century Portrait. New York: 1988.

Budillon, J. Le Ministere Chez Les reformes de langue française, in Istina, 196162,3 .

Buckler, Andrew. Jean Calvin et la mission de l'église. Lyon: Olivetan, 2008. 
Carbonnier-Burkard, Marianne. "Calvin dresseur d'églises". Jean Calvin. Les visages multiples d'une reforme et de sa reception. Edited by Bolliger and others. Lyon: Olivetan, 2009.

Burnett, Amy Nelson. The Yoke of Christ. Martin Bucer and Christian Discipline.

Cadier, Jean. Calvin: Sa vie, son oeuvre avec un expose de sa philosophie. Paris: 1967.

Calhoun, David B. "John Calvin: Missionary Hero or Missionary Failure, Presbyterion. Covenant Seminary Review, 5.1 (1979). Calvin Studies. I-VII: 1976-1994.

Cottret, Bernard. Calvin.Biographie. Paris: J. C. Lattes, 1995.

Courvoisier, Jaques. "Les Cathechismes de Geneve et de Strasbourg. Etude sur le developpment de la pensee de Calvin". Bulletin de la Société de l'histoire du Protestantisme Français (1935): 105-121.

. De la reforme au protestantisme. Essai d'ecclesiologie reformee. Paris: Beauchesne, 1977.

. La notion de l'église chez bucer. Paris: Editions Cerf, 1935.

Crottet, A. Correspondance française de Calvin avec Louis du Tillet (1537-38). Geneva: Cherbuliez, 1850.

Denis, Philippe. Les églises d'etrangers en pays Rhenans (1538-1564). Paris: 1984.

Doumergue, Emile. Jean Calvin. Les hommes et les choses de son temps. Tome 4. La Pensee de Calvin. Lausanne: Georges Bridel, 1910.

Edwards, Charles E. "Calvin and Missions". The Evangelical Quarterly 8 (1936).

Eells, Hastings. Martin Bucer. New Haven: Yale University Press, 1931.

Erichson, Alfred. L'église française de Strasbourg au seizième siécle d'apres des documents inedits. Strasbourg, 1886.

Freudenberg, Matthias. Katechismen in Calvin Handbuch. Edited by Herman J. Selderhuis. Tübingen, 2008.

Ganoczy, Alexandre. Calvin. Theologien de l'église et du ministere. Paris: Le Cerf, 1964.

Godfrey, Robert, W. John Calvin. Pilgrim and Pastor. Wheaton, IL: Crossway, 2009

Goumaz, L. Timothee. Le ministère évangelique, d'apres les commentaires de Calvin sur le N. T. Lausanne: La Concorde, 1948.

DeGreef, W. The Writings of John Calvin. Grand Rapids, MI: Baker, 1993.

Hall, David, W. and Peter A. Lillback., eds. Theological Guide to Calvin's Institutes. Phillipsburg, NJ: P \& R, 2008. 
. Tributes to John Calvin. Phillipsburg, NJ: P \& R, 2010.

Hall, Joseph, H. "Reformed Catechetics". Concordia Journal (1979): 205-210.

Hammann, Gottfried. Entre la sect et la cité. Le projet d'église du reformateur Martin Bucer. Geneva: Labor et Fides, 1984.

Hirzel, Martin Ernst and Martin Sallmann, eds. Calvin et le calvinisme. Cinq siècles d'influences sur l'église et la société. Geneva: Labor et Fides, 2008.

Hoepfl, Harro. The Christian Polity of John Calvin. Cambridge: Cambridge Press, 1982.

Hughes, Philip E. "John Calvin: Director of Missions". The Heritage of John Calvin. Edited by J. H. Bratt, 40-54. Grand Rapids, MI: William B. Eerdmans, 1973.

. The Register of the Company of Pastors of Geneva in the Time of Calvin. Grand Rapids, MI: William B. Eerdmans Publishing Company, 1966.

Hulse, Erroll. John Calvin and his Missionary Enterprise. N. D.

James, Frank, III. "Calvin and Missions". Christian History 5.4 (1986).

Joisten, Hartmut. Martin Bucer. Un reformateur europeen. Strasbourg: Oberlin, 1991.

Kampshulte, F. W. Johann Calvin. Seine Kirche und sein Staat in Genf. Two volumes. Leipzig: Duncker and Humblot, 1869-1899.

Kingdon, Robert. "A Fresh Look at Calvin's Attempt to Introduce Discipline into a Reformed Community". Calvin-France-South Africa. Papers of the Third South African Congress on Calvin Research. Edited by A. D. Pont. Kital: Pretoria, 1990.

Klaassen, Walter. Anabaptism in Outline. Scottdale, PA: Herald, 1981.

Koekemoer, J. H. "Catechesis in Light of Calvin's Institutes". Potchefstroom, 1986.

Kromsigt, P. J. "Calvins Lehre von der Kirche”. Biblische Zeugnisse 22 (1924): 45-76.

Krumenacker, Yves. Calvin. Au-del a des legendes. Paris: 2009.

Kuyper, Abraham. Lectures on Calvinism. Peabody, MA: Hendrickson. 2008.

MacMillan, J. Douglas. "Calvin, Geneva, and Christian Mission", Reformed Theological Journal 5 (1989).

McNeill, J. T. "The Doctrine of the Ministry in Reformed Theology". Church History 12.2 (1943). . The History and Character of Calvinism. London: Oxford University Press, 1967.

Millet, Olivier. Calvin, un homme, une oeuvre, un auteur. Gollion, 2008. . Calvin et ses contemporains. Geneva: Droz, 1998. 
Milner, Benjamin Charles. Calvin's Doctrine of the Church. Leiden: Brill, 1970.

Mulhaupte, E. Die Predigt Calvins, ihre Geschicte, ihre Form une ihre religiosen Grundgedanken. Berlin: De Gruyter, 1931.

Niesel, W. Die Theologie Calvins. Munchen: Kaiser, 1957.

Osment, Steven E. The Reformation in the Cities. New Haven: Yale University Press, 1975.

Pannier, J. "Calvin et l'episcopat". Istra Cahiers de la RHPR. Srasbourg, 1927. . "Recherches sur la formation intelectuelle de Calvin". Cahiers de la RHPR 24. Paris: Alcan, 1931. . Calvin a Strasbourg. Paris: 1925.

Parker, T. H. L. John Calvin. A Biography. Oxford: Lion, 2006.

Peter, Rodolphe. Les premiers uovrages français imprimes a Strasbourg. Annuaire de la Societe des Amis du Vieux Strasbourg 3, 1974.

. "Calvin et la liturgie d'apres l'institution de la réligion chrètienne de Calvin". Revue Française d'Histoire du Livre 54, 1986.

. et Jean-Francois Gilmont. Biblioteca Calviniana. Les oeuvres de Jean Calvin publies au XVI Siecle. I. Ecrits theologiques, litteraires, et juridiques (1532-1554). Geneva: Droz, 1991.

Parsons, Burk, ed. John Calvin. A Heart for Devotion, Doctrine, and Doxology. Orlando, FL: Reformation Trust, 2008.

Pettegree, Andrew. Calvinism in Europe. Cambridge: Cambridge University Press, 1996.

Pollet, J. V. Martin Bucer. Paris: Presses Universitaire, 1962.

Rahner, Karl. Das Dynamische in der Kirche in Quaestiones Disputatae 5. Frieburg: Herder, 1958.

Reid, W. Stanford. “Calvin's Geneva: A Missionary Centre”. The Reformed Theological Review 42.3 (1983).

Rodolphe, Peter and Jean-Francois Gilmont. Biblioteca Calviniana. Les oeuvres de Calvin publiès au XVI Siècle. 1. Écrits théologiques, litteraires, et juridiques 1532-1554. Geneva, 1991.

Rott, Jean. "Léglise des réfugiès de la langue française à Strasbourg" BSHPF 122, 507-524.

_. "Documents strasbourgeois concernant Calvin". Regards Contemporains sur Calvin. Paris: 1965.

. Strasbourg au coeur religieux du XVIe siècle. Strasbourg: Istra, 1977.

Spijker, Willem Van't. "The Influence of Bucer on Calvin as becomes Evident from the Institutes”. John Calvin's Institutes. His Opus Magnum. Edited by B. J. Van Der Walt. Potchefstroom, 1986. 
. "De Ambten Bij Martin Bucer". Kampen: J. H. Kok, 1970.

Stern, Edmond. "La theorie de culte d'apres Calvin". Calviniana. Tome III. Strasbourg: Univérsité de France, 1865-1869.

Strohl, H. "La notion de l'église chez les reformateurs". La RHPR, Strasbourg, 1936.

. "La theorie et la pratique des quatres ministeres a Strasbourg avant l'arrivée de Calvin". Le bulletin de la soc. de l'hist. du prot. franc. 84 (1935).

Strohm, Christoph. "Beobachtungen Zur Eigenart der Theologie Calvins". Evangelische Theologie 69 (2009).

Torrance, Thomas F. Kingdom and Society. A Study in the Theology of the Reformers. Edinburgh: Oliver and Boyd, 1956.

. The School of Faith. Catechisms of the Reformed Church. New York, NY: Harper, 1959.

Wendel, F. Calvin. Sources et evolution de sa pensee religieuse. Paris: Presses Universitaires de France, 1950.

. L'église de Strasbourg, sa constitution et son organization (1532-1535). Paris, 1942.

Williams, G. H. The Radical Reformation. Kirksville, MO: Truman State, 2000.

Williams, Garry J. and Joel R. Beeke, eds. Calvin. Theologian and Reformer. Grand Rapids, MI: Reformation Heritage, 2010.

Van den Berg, J. "Calvin and Missions". John Calvin. Contemporary Prophet, 167-83. Edited by J. Hoogstra. Philadelphia: Presbyterian \& Reformed, 1959.

Van't Veer, M. B. Catechese en Catechetische Stof Bij Calvin. Kampen: J. H. Kok, 1942.

Walker, Williston. John Calvin. The Organizer of Reformed Protestantism 15091564. New York, NY: Knickerbocker Press, 1906.

Will, Robert. "La premier liturgie de Calvin". Revue d'Histoire et de Philosophie Religieuses 18 (1938).

Zwemer, Samuel. "Calvinism and the Missionary Enterprise". Theology Today 7 (1950).

Periodicals and Other Sources

Amos, N. Scott. "Martin Bucer and the Revision of the 1549 Book of Common Prayer: Reform of Ceremonies and the Didactic Use of Ritual”. Reformation \& Renaissance Review 2 (1999): 107-126. 
"Martin Bucer: A Reformer and His Times/Eucharistic Sacrifice and Patristic Tradition in the Theology of Martin Bucer 1534-1546”. Renaissance Quarterly 58.4 (2005): 1362.

Arnold, Matthieu, Martin Bucer, Jean Rott, Reinhold Friedrich, and Christian Krieger. Correspondance de Martin Bucer, III. 1527-1529. Studies in Medieval and Reformation Thought. Leiden: E. J. Brill, 1995.

Backus, Irena. "La théorie logique de Martin Bucer: La prédication Chez P. Crockaert, Georges De Trébizonde, R. Lever et M. Bucer”. Cahiers de la revue de théologie et de philosophie 5 (1980): 27-39.

Basse, Michael. Calvin und seine Wirkungsgeschichte. Berlin: LIT Verlag, 2011.

Barbara, Pitkin. "Seeing and Believing in the Commentaries on John by Martin Bucer and John Calvin". Church History 68.4 (1999): 865.

. "Marriage and Divorce in the Thought of Martin Bucer". Church History 69.4 (2000): 894.

Joel Beeke. John Calvin. Teacher and Practitioner of Evangelism. Grand Rapids: Pilgrim, 2008.

Bodenmann, Reinhard. "Martin Bucer 1491 à 1991: Plaidoyer pour une nouvelle bibliographie". Martin Bucer and Sixteenth Century Europe, 733752. Leiden: E. J. Brill, 1993.

- "Martin Bucer Et Gaspard Hédion: Vicissitudes Des Relations Entre Deux Collìgues, 1523-1549". Martin Bucer and Sixteenth Century Europe, 297-315. Leiden: E. J. Brill, 1993.

Brady, Thomas A., Jr. "The Earth Is the Lord's, and Our Homeland as Well': Martin Bucer and the Politics of Strasbourg". Martin Bucer and Sixteenth Century Europe, 129-143. Leiden: E J Brill, 1993.

Bryan, D. Spinks. "Martin Bucer. Reforming Church and Community". Scottish Journal of Theology 52.3 (1999): 403.

Buckwalter, Stephen E. "Reformation und Einheit der Kirche: Martin Bucers Einigungsbemühungen bei den Religionsgesprächen in Leipzig, Hagenau, Worms, Und Regensburg, 1539-1541". Zeitschrift für Kirchengeschichte 115.1-2 (2004): 257-259.

Burger, Christoph. "Wij Geloven in God En in Christus. Niet in De Kerk'. Wessel Gansfort (1489) en Martin Bucer (1551). Met Een Woord Van Augustinus En Een Geschrift Van Wessel. Uit De Bronnen Vertaald En Toegelicht". Church History and Religious Culture 86.1-4 (2006): 321-324.

Burnett, A. "Martin Bucer zwischen Luther und Zwingli". The Journal of Ecclesiastical History 56.2 (2005): 384. 
Burnett, Amy Nelson. "Book Reviews. Martin Bucer und Johannes Calvin. Reformatorische Perspektiven. Einleitung und texte by Marijn De Kroon". The Sixteenth Century Journal 24.2 (1993): 459.

. "Confirmation and Christian Fellowship. Martin Bucer on Commitment to the Church". Church History 64.2 (1995): 202-217.

. "Confirmation and Christian Fellowship. Martin Bucer on Commitment to the Church". Church History 64.2 (1995): 202.

. "Correspondance de Martin Bucer. Tome 3 (1527-1529)". The Sixteenth Century Journal 27.3 (1996): 801.

. "Martin Bucer. Reforming Church and Community". The Catholic Historical Review 82.4 (1996): 708.

. "Martin Bucer and the Church Fathers in the Cologne Reformation". Reformation \& Renaissance Review 3.1-2 (2001): 108-124.

. "Martin Bucers Deutsche Schriften. VIII, Abendmahlsschriften, 1529-1541”. Sixteenth Century Journal 40.2 (2009): 549-550.

Campi, Emidio. "Reich Christi und Obrigkeit: Eine Studie zum Reformatorischen Denken und Handeln Martin Bucers". Zwingliana 33 (2006): 242-246.

Dingel, Irene. "Martin Bucer (1491-1551): Bibliographie". Theologische Lieteraturzeitung 132.1 (2007): 56-60.

Duke, James O. "Martin Bucer and 16th Century Europe. Actes du Colloque de Strasbourg, 28-31 Août 1991, 2 V”. Encounter 59.3 (1998): 430433.

Edwards, Kathryn. "The Yoke of Christ. Martin Bucer and Christian Discipline”. Historian 59.1 (1996): 180.

Eells, Hastings. "The Contributions of Martin Bucer to the Reformation". Harvard Theological Review 24.1 (1931): 29-42.

Engelsma, David J. "Martin Bucer: Reformed Pastor of Strasbourg”. MidAmerica Journal of Theology 3.1 (1987): 35-63.

. 'Martin Bucer. 'Fanatic of Unity'. Mid-America Journal of Theology 4.1 (1988): 32-53.

Fink, David C. “The Doers of the Law Will Be Justified'. The Exegetical Origins of Martin Bucer's Triplex Iustificatio". Journal of Theological Studies 58.2 (2007): 485-524.

Frank, A. James, III. "Marriage and Divorce in the Thought of Martin Bucer”. The Sixteenth Century Journal 32.1 (2001): 251.

Friedrich, Reinhold. Martin Bucer "Fanatiker der Einheit?" Seine Stellungnahme zu Theologischen Fragen seiner Zeit (Abendmahls und Kirchenverständnis) Ins- 
besondere Nach Seinem Briefwechsel Der Jahre 1524-1541. Biblia et Symbiotica. Bonn: Verlag für Kultur und Wissenschaft, 2002.

Fruge, Eric William. "Anabaptism and the Reformation in France, 15341648". 9311163, Southwestern Baptist Theological Seminary, 1992.

Furcha, E. J. "The Holy Spirit in the Theology of Martin Bucer". Journal of the Canadian Church Historical Society 12.3 (1970): 58-59.

Gordon, A. Jensen. "Martin Bucer. A Reformer and His Times". Anglican Theological Review 88.1 (2006): 115.

Gordon, Bruce. Calvin. New Haven: Yale, 2009.

Greschat, Martin. "Das Profil Martin Bucers". Martin Bucer and Sixteenth Century Europe, 9-17. Leiden: E. J. Brill, 1993.

Greschat, Martin, and Stephen E. Buckwalter. Martin Bucer. A Reformer and His Times. Louisville, KY: Westminster John Knox Press, 2004.

Greschat, Martin, and Gotthelf Wiedermann. "Martin Bucer and Church Renewal in Europe". Reformation \& Renaissance Review 5.1 (2003): 92101.

Grosse, Sven. Johannes Calvin. Streiflichter auf den Menschen und Theologen. Vorträge und Tagungsbeiträge an der Staatsunabhängigen Theologischen Hochschule Basel zum Calvin-Jahr 2009. Berlin: LIT Verlag, 2011.

Hamm, Berndt, and Helen Heron. "Tolerance and Heresy. Martin Bucer's Radical New Definition of Christian Fellowship". Politics and Reformations, 269-291. Leiden, Boston: Brill, 2007.

Hammann, Gottfried. "Les motifs ecclésiologiques Sous-Jacents à la création des Christlichen Gemeinschaften par Martin Bucer à Strasbourg en 1546-1548". Bulletin de la société de l'histoire du protestantisme français 139.2 (1993): 167-186.

Harrison, Richard L. "Martin Bucer on the Nature and Purpose of Ministry: The View from Exile”. Lexington Theological Quarterly 16.2 (1981): 5367.

Harrison, Richard L., Jr. "Martin Bucer: Reforming Church and Community”. Church History 66.1 (1997): 114-115.

. "The Yoke of Christ: Martin Bucer and Christian Discipline". Church History 66.1 (1997): 113-114.

Hazlett, Ian. "Eucharistic Communion: Impulses and Directions in Martin Bucer's Thought". Martin Bucer, 72-82. Cambridge: Cambridge University Press, 1994.

Hobbs, R. Gerald. "Martin Bucer et les Juifs". Martin Bucer and Sixteenth Century Europe, 681-689. Leiden: E. J. Brill, 1993. 
Jeffrey, Gros. "Martin Bucer: A Reformer and His Times". Journal of Ecumenical Studies 41.1 (2004): 104.

Kenneth, Stevenson. "Eucharistic Sacrifice and Patristic Tradition in the Theology of Martin Bucer 1534-1546. Edited by Nicholas Thompson, xvi, 315. Studies in the History of Christian Traditions, 119. Leiden: Brill, 2005, Journal of Theological Studies 57.1 (2006): 372.

Kittelson, James Matthew. "Martin Bucer: Forgotten Man in the Late 16th Century?" Martin Bucer and Sixteenth Century Europe, 705-714. Leiden: E. J. Brill, 1993.

. "Martin Bucer and the Ministry of the Church". Martin Bucer, 83-94. Cambridge: Cambridge University Press, 1994.

Koch, Gustave, and Paul Ayris. "The Christian Life in the Light of the 'Summary' of Martin Bucer of 1523”. Reformation \& Renaissance Review 3.1-2 (2001): 140-151.

Kraft, Sigisbert. "Martin Bucers Theologie-Eine Wegweisung im Ökumenischen Gespräch”. Ökumenische Rundschau 50.4 (2001): 524-535.

Krahn, Henry G. "Martin Bucer's Strategy against Sectarian Dissent in Strasbourg”. Mennonite Quarterly Review 50.3 (1976): 163-180.

Krieger, Christian. "Réflexions sur la place de la doctrine de la prédestination au Sein de la Théologie de Martin Bucer". Martin Bucer and Sixteenth Century Europe, 83-99. Leiden: E. J. Brill, 1993.

Laurel, Carrington. "Martin Bucer und das Recht: Beiträge zum Internationalen Symposium vom 1. Bis 3. März 2001 in der Johannes à Lasco Bibliothek Emden". Renaissance Quarterly 57.3 (2004): 1050.

Lee, Canipe. "Marriage and Divorce in the Thought of Martin Bucer". Journal of Church and State 44.2 (2002): 377.

Lee Palmer, Wandel. "Eucharistic Sacrifice and Patristic Tradition in the Theology of Martin Bucer, 1534-1546". The American Historical Review 110.5 (2005): 1612.

Lienhard, Marc. "Martin Bucer le réformateur européen". Communio viatorum 34.2 (1992): 15-34.

. "Le retour de Martin Bucer". Martin Bucer and Sixteenth Century Europe, 3-8. Leiden: E. J. Brill, 1993.

Lindberg, C. "Religion-Martin Bucer: Reforming Church and Community". Edited by D. F. Wright. Choice 32.4 (1994): 617.

Loewe, Andreas. "Martin Bucers Deutsche Schriften. VIII, Abendmahlsschriften, 1529-1541". Journal of Ecclesiastical History 57.2 (2006): 369370. 
Matheson, Peter. "Martin Bucer and the Old Church". Martin Bucer, 5-16. Cambridge: Cambridge University Press, 1994.

Mattox, M. "Eucharist Sacrifice and Patristic Tradition in the Theology of Martin Bucer 1534-1546". The Sixteenth Century Journal 39.4 (2008): 1137.

Meyerhoff, D. Steven. "Martin Bucer: Pioneer of Liturgical Reform". Presbyterion 17.2 (1991): 113-118.

Mullinax, Allen B. "Musical Diversity in Reformation Strasbourg: Martin Bucer's Strasbourg Song Book (1541)”. Hymn 45 (1994): 9-13.

Nassen, W. "Martin Bucers Hermeneutik". Mennonite Quarterly Review 42.4 (1968): 332-318.

Neuser, Wilhelm H. "Martin Bucer und die Union". Vielfalt in der Einheit, 113-123. Speyer, Germany: EPV, 1993.

Noblesse-Rocher, Annie. "Du commentaire à l'assomption par l'ésprit. Quelques remarques relatives à la prédication de Martin Bucer". Annoncer l'évangile (XVe-XVIIe siècle), 87-99. Paris: Éditions du Cerf, 2006.

Partee, Charles. The Theology of John Calvin. Louisville: Westminster JohnKnox, 2008.

Peachey, Paul. "Entre la secte et la cite. Le projet d'église du réformateur Martin Bucer". Mennonite Quarterly Review 60.2 (1986): 220-221.

Pils, Holger, Stephan Ruderer, and Petra Schaffrodt. Martin Bucer (14911551). Bibliographie. Gütersloh: Gütersloher Verlagshaus, 2005.

Richard, L. Harrison, Jr. "Martin Bucer. Reforming Church and Community". Church History 66.1 (1997): 114.

. "The Yoke of Christ. Martin Bucer and Christian Discipline". Church History 66.1 (1997): 113.

Roth, John D. and Stayer, James M. eds. A Companion to Anabaptism and Spiritualism, 1521-1700. Leiden: Brill, 2007.

Schaeffer, Peter. "Book Reviews. Correspondance de Martin Bucer (Tome I: Jusqu'en 1524). Edited by Jean Rott / Correspondance de Martin Bucer. Tome II: 1524-1526. Edited by Jean Rott with the Collaboration of Reinhold Friedrich”. The Sixteenth Century Journal 22.1 (1991): 155.

Selderhuis, Herman. "Vera Theologia Scientia Est: Bucer and the Training of Ministers". Reformation \& Renaissance Review. Journal of the Society for Reformation Studies 3.1-2 (2001): 125. . The Calvin Hanbook. Grand Rapids: Eerdmans, 2008. 
Spijker, W. van 't. "Vera ecclesiae concordia: Martin Bucer's Blueprint for the Reformation in France". Adaptations of Calvinism in Reformation Europe, 111-126. Aldershot, England \& Burlington, VT: Ashgate, 2007.

Stevenson, Kenneth W. Bp. "Eucharistic Sacrifice and Patristic Tradition in the Theology of Martin Bucer, 1534-1546". Journal of Theological Studies 57.1 (2006): 372-376.

Thompson, Nicholas. "Martin Bucer's Assessment of the Canon of the Mass in the Era of the Religious Colloquies". Reformation \& Renaissance Review 3.1-2 (2001): 51-77.

Wainwright, Geoffrey. "Eucharistic Sacrifice and Patristic Tradition in the Theology of Martin Bucer, 1534-1546”. Worship 81.4 (2007): 361-362.

Wanegffelen, Thierry. "Un sorbonniste contre Bucer. La réfutation des idées de Martin Bucer par l'évêque d'avranches Robert Céneau (Septembre 1534)". Revue d'histoire et de philosophie religieuses 73.1 (1993): 2337.

Wright, D. F. "The Yoke of Christ. Martin Bucer and Christian Discipline". The Journal of Ecclesiastical History 47.3 (1996): 573.

Wright, D. F. Martin Bucer. Reforming Church and Community. Edinburgh: University Press, 1994.

Wulczyn, Heidi. "The Relationship between Martin Bucer and Philip of Hesse. A Reforming Politician and a Political Reformer, 1534-1539". Martin Bucer and Sixteenth Century Europe, 451-459. Leiden: E. J. Brill, 1993.

Wyneken, C. H. "Calvin and Anabaptism". Concordia Theological Monthly 36.1 (1965): 18-29.

Papers

Yarnell, Malcolm, "Baptists: Are We Calvinists or Non-Calvinists?" Paper presented at the annual Société d'Histoire et de Documentation Baptistes de France, Paris, France, 29 November 2010. 